УДК 577.188:599.323.4

doi: $10.36359 /$ scivp.2019-20-2.39

\title{
ВИВЧЕННЯ ПОКАЗНИКІВ НЕШКІДЛИВОСТІ МОДИФІКОВАНОГО КРОХМАЛЮ НА БІЛИХ МИШАХ
}

\author{
А. Г. Вовкогон, канд. с.-г. наук
}

\begin{abstract}
Білоцерківський національний аграрний університет Соборна Площа, 8/1, м. Біла церква, 09117, Україна
\end{abstract}

Крохмаль має широке використання в харчовій промисловості. Проте фізико-хімічні властивості дають змогу використовувати ией вуглевод в інших галузях народного господарства. Сорбиійні властивості крохмалю дозволяють приєднувати до нього органічні сполуки в тому числі ензими та клітини мікроорганізмів. Крохмаль може виступати носієм для іммобілізачії мікроорганізмів. Переваги крохмалю як носія полягають у його доступності, відновлюваності та відносно невисокій вартості. Для збільшення місткості крохмалю як носія в лабораторії НДІ харчових технологї̈ і технологій переробки продукції тваринництва Білочерківського начіонального аграрного університету проведено комплекс робіт із його модифікачії фізико-хімічними методами.

Використання модифікованого крохмалю як носія для іммобілізачії клітин мікроорганізмів заквасок для кисломолочних продуктів передбачає вивчення його нешкідливості. Дані дослідження було проведено на лінійних мишах із масою тіла 19-21 2. Модифікований крохмаль дослідним тваринам водили внутрішньошлунково за допомогою металевого зонду. По завершенню досліду тварин забивали, відбирали тканини і органи для проведення біохімічних досліджень.

Експериментально встановили, що за внутрішньошлункового введення мишам по 0,3 $\mathrm{cm}^{3}$ 5,0\% та 10,0\% розчину модифікованого крохмалю захворювань та загибелі тварин протягом усього експерименту не відмічалось. Етологія тварин була аналогічною контрольним мишам. Введення підвищених доз модифікованого крохмалю не вплинуло на зовнішній вигляд печінки, селезінки, нирок та органів травлення тварин.

Дослідженнями показників білкового обміну було доведено, що активність аспартатамінотрансферази та аланінамінотрансферази у печінці мишей, яким водили модифікований крохмаль вірогідно не відрізнялась від аналогічних даних у тварин, яким водили фізіологічний розчин. Різниия щзодо вмісту загального білка у печіниі та сечовини у крові дослідних і контрольних тварин не мала вірогідного характеру. Гемоглобін у крові мишей після внутрішньошлункового введення їм різних доз досліджуваного фактора був в межах фізіологічної норми.

Ключові слова: МОДИФІКОВАНИЙ КРОХМАЛЬ, ВНУТРІШНЬОШЛУНКОВЕ ВВЕДЕННЯ, БІЛОК, АМІНОТРАНСФЕРАЗИ, ПОКАЗНИКИ БІЛКОВОГО ОБМІНУ, ЛАБОРАТОРНІ ТВАРИНИ.

Виробництво полісахариду крохмалю, як біополімерної сполуки, із різної сировини має свої особливості. Основною сировиною для одержання крохмалю є зерно кукурудзи, сорго, пшениці, рису та бульби (топінамбур, картопля, тапіока) [1-3]. Розроблені технології виробництва крохмалю із мікроводоростей та амаранту [4, 5]. Як джерело крохмалю застосовують маніоку, банани, кедрові горіхи тощо [6-8].

Як нативний, так і модифікований крохмаль використовується у різних галузях народного господарства. Хімічна будова крохмалю, його властивості та відновлюваність дають йому змогу виступати у ролі носія для іммобілізації ензимів та клітин мікроорганізмів 
[9, 10]. Відсутність специфічного кольору та запаху крохмалю [2], а також властивість адсорбції [11-13] дозволяє проводити на ньому іммобілізацію заквасок, як харчових добавок.

Для підвищення сорбційних властивостей крохмалю фізико-хімічним методом проведено його модифікацію. Залишаються невідомими властивості модифікованого крохмалю щодо його нешкідливості, як нового носія для іммобілізації мікроорганізмів заквасок для кисломолочних продуктів і як харчової добавки.

Крохмаль відноситься до поширених полісахаридів, які синтезуються рослинами. Будова крохмалю представлена двома полімерами амілозою та амілопектином. Мономером у цій структурі є глюкоза.

Крохмаль застосовується в різних сферах. У раціонах сільськогосподарських тварин та людини 35 \% і більше енергії припадає на крохмаль. Згідно світової практики дві третини виробленого крохмалю використовується в харчовій промисловості. Решта поліцукру задіюється в непродовольчих галузях [14].

3 кожним роком все ширше поширюється використання крохмалю в галузях, які не відносяться до продовольчої сфери. Крохмаль застосовується для виробництва зклеювальних матеріалів, як цементуюча основа для зменшення часу стабілізації, у текстильній та паперовій промисловості у ролі наповнювача і як засіб для поліпшення адгезії фарби. Крохмаль застосовують як зволожувач, загущувач та наповнювач під час виробництва фармацевтичної та косметичної продукції. Розроблені технології застосування природнього поліцукру за виробництва пластмасових виробів та пакувальних матеріалів для харчових продуктів, харчових контейнерів. Крохмаль застосовується в аграрній сфері [15].

Придатність до гелеутворення, властивість крохмалю адсорбувати білкові молекули та клітини мікроорганізмів дає змогу застосовувати поліцукор у біотехнологічних операціях їх іммобілізації для харчової промисловості [10]. Модифікація крохмалю надає йому ряд нових властивостей. Застосування нових харчових добавок або добавок із новими властивостями вимагає перевірки їх на нешкідливість [16].

Метою досліджень $є$ встановлення нешкідливості модифікованого крохмалю, як носія для іммобілізації ензимів та заквасок для кисломолочних продуктів за допомогою білих мишей.

Матеріали i методи. Перевірка нешкідливості модифікованого крохмалю здійснювалась на лабораторних тваринах (білі миші) [16]. Для експерименту було відібрано 18 самок мишей віком 62 доби і масою 19-21 г. Під час формування груп звертали увагу на клінічний стан лабораторних тварин. У кожній групі було по 6 клінічно здорових тварин.

Перед дослідженням виготовляли 5,0 та 10,0 \% розчини модифікованого крохмалю, які водили лабораторним тваринам зондом внутрішньошлунково.

Контрольні тварини одержували одноразово по $0,3 \mathrm{~cm}^{3}$ фізіологічного розчину. Мишам I дослідної групи було введено по $0,3 \mathrm{~cm}^{3}$ розчину модифікованого крохмалю. Для тварин II дослідної групи одноразова доза залишалась сталою $\left(0,3 \mathrm{~cm}^{3}\right)$ проте розчин містив 10,0 модифікованого крохмалю (табл. 1).

Таблиия 1

Схема проведення експерименту

\begin{tabular}{|c|c|l|}
\hline Групи & Кількість тварин у групі, гол. & \multicolumn{1}{|c|}{ Розчин, що вивчається та їх дози ведення } \\
\hline Контрольна & 6 & Фізіологічний розчин (об’єм $\left.0,3 \mathrm{~cm}^{3}\right)$ \\
\hline I дослідна & 6 & $5,0 \%$ розчин модифікованого крохмалю (об'єм $\left.0,3 \mathrm{~cm}^{3}\right)$ \\
\hline II дослідна & 6 & $10,0 \%$ розчин модифікованого крохмалю (об'єм $\left.0,3 \mathrm{~cm}^{3}\right)$ \\
\hline
\end{tabular}

Постійний нагляд за піддослідними мишами здійснювали продовж 10 діб. На одинадцяту добу після ведення досліджуваних розчинів за анестезії проводили декапітацію та розтин з послідуючим патолого-анатомічним дослідженням внутрішніх органів тварин. 
Із відібраних зразків печінки мишей виготовляли гомогенат, у якому визначали активність амінотрансфераз - за S. Reitman, S. Frrancel [17], вміст загального білка - за O. H. Lowry [18]. У крові визначали вміст гемоглобіну згідно з інструкцією [19] та сечовини згідно з інструкцією [20].

Результати й обговорення. За безперервного спостереження протягом перших 24 годин лабораторні тварини у контрольній групі мали сталу поведінку. Періодично поїдали комбікорм та пили воду. Миші із І дослідної групи мали аналогічну поведінку, що і у контролі. Тварини на дотик, світло, шум та вібрації реагували адекватно.

Встановлено, що миші із II дослідної групи протягом перших 3-4 годин після внутрішньошлункового введення модифікованого крохмалю не підходили до корму і води. У цей період на зовнішні подразники реагували. У 33,3 \% тварин було виявлено розлад шлунково-кишкового тракту. На п'яту годину спостереження миші відновили споживання корму та води.

Із другої до десятої доби у тварин із контрольної, I та II дослідної групи порушень апетиту, відмови від води та неприродних рухів не спостерігалось. Збереженість мишей на кінець досліду по групах становила по 100,0 \%. За патолого-анатомічних досліджень системи травлення мишей виявлено, що за розмірами, станом та кольором слизових оболонок стравохід, шлунок, тонкий та товстий відділ кишківника тварин із дослідних груп нічим не різнився із даними показниками у контролі. Паренхіматозні органи мишей I та II дослідної групи за морфологічними ознаками були аналогічними, що у тварин контрольної групи.

Таким чином, одноразові підвищені дози модифікованого крохмалю $є$ не шкідливими для лабораторних тварин, що підтверджується відсутністю захворювання, загибелі мишей та відсутністю морфологічних змін їх внутрішніх органів.

Враховуючи той факт, що токсичні речовини потрапляючи у організм порушують метаболічний процес у клітинах і тканинах тварин нами було проведено дослідження щодо впливу внутрішньошлункового введення модифікованого крохмалю на білковий обмін у організмі мишей.

Уміст загального білка у печінці мишей із контрольної групи був на рівні 67,2 г/кг. У мишей, яким одноразово водили $0,3 \mathrm{~cm}^{3} 10,0 \%$ розчину модифікованого крохмалю вміст білка у печінці був вищим у порівняні із контролем на 5,9\%. Проте різниця не мала вірогідного значення. За вмістом загального білка не виявлено вірогідної різниці із контролем у тварин I дослідної групи (табл. 2).

Деякі показники білкового обміну в печінці лабораторних тварин, $\mathrm{M} \pm \mathrm{m}, \mathrm{n}=6$

Таблиия 2

\begin{tabular}{|l|c|c|c|}
\hline \multicolumn{1}{|c|}{ Групи } & Вміст загального білка, г/кг & $\begin{array}{c}\text { Активність ензиму АсАТ, } \\
\text { мкмоль/год/г }\end{array}$ & $\begin{array}{c}\text { Активність ензиму АлАТ, } \\
\text { мкмоль/год/г }\end{array}$ \\
\hline Контрольна & $67,2 \pm 4,67$ & $10,3 \pm 0,72$ & $14,2 \pm 0,53$ \\
\hline I дослідна & $70,3 \pm 3,34$ & $9,8 \pm 0,53$ & $13,7 \pm 0,42$ \\
\hline II дослідна & $71,2 \pm 4,12$ & $11,1 \pm 0,47$ & $13,2 \pm 0,49$ \\
\hline
\end{tabular}

Актинівсть аспартатамінотрансферази (АсАт) у печінці лабораторних тварин, які належали до контрольної групи була в межах 10,3 мкмоль/год/г. Ведення 0,3 cм 3 5,0 \% розчину модифікованого крохмалю не впливало на вірогідне зниження активності АсАт у мишей відносно контролю. Різниця була в межах похибки. Активність ензиму у печінці тварин із II дослідної групи теж вірогідно не відрізнялась від цього показника у мишей контрольної групи.

У печінці мишей із контрольної групи активність ензиму аланінамінотрансферази (АлАт) становила 14,2 мкмоль/год/г. На 11 добу після ведення досліджуваних факторів не встановлено впливу модифікованого крохмалю на вірогідну зміну активності АлАт у печінці тварин із дослідних груп. 
Ще одним із показників білкового обміну у тваринному організмі є вміст сечовини. Сечовина є кінцевим продуктом розпаду білка. Вміст сечовини визначали у крові піддослідних тварин. У мишей контрольної групи вміст сечовини у крові був на рівні 4,3 ммоль/л. Зростання вмісту сечовини у крові мишей I дослідної групи було у межах похибки відносно контролю. Ведення лабораторним тваринам $0,3 \mathrm{~cm}^{3} 10,0 \%$ розчину модифікованого крохмалю не супроводжувалось вірогідним зниженням катаболізму білка і накопичення сечовини у крові (табл. 3).

Біохімічні показники крові мишей, $\mathrm{M} \pm \mathrm{m}, \mathrm{n}=6$

\begin{tabular}{|l|c|c|}
\hline \multicolumn{1}{|c|}{ Групи } & Уміст гемоглобіну, г/л & Уміст сечовини у крові, ммоль/л \\
\hline Контрольна & $121,1 \pm 3,46$ & $4,3 \pm 0,45$ \\
\hline I дослідна & $124,2 \pm 5,17$ & $4,7 \pm 0,36$ \\
\hline II дослідна & $119,3 \pm 4,27$ & $4,0 \pm 0,83$ \\
\hline
\end{tabular}

Вміст гемоглобіну у крові мишей із контрольної та дослідних груп був в межах фізіологічної норми. Вірогідних відхилень цього показника між групами не виявлено.

Отже, експериментально доведено, що ведення мишам внутрішньошлунково по $0,3 \mathrm{~cm}^{3}$ $5,0 \%$ та 10,0 \% розчину модифікованого крохмалю не має негативної дії на метаболічні (анаболізм, катаболізм) процеси пов'язані із білком та вмістом гемоглобіну у організмі тварин.

\title{
В И С Н О В К И
}

1. За одноразового введення внутрішньошлунково мишам $0,3 \mathrm{~cm}^{3} 5,0 \%$ та 10,0 \% розчинів модифікованого крохмалю летальних випадків тварин не відмічається.

2. Під час вивчення нешкідливості модифікованого пектину показники білкового обміну у організмі мишей вірогідно не змінюються.

Перспективи досліджень. Науковий інтерес представляє визначення гострої токсичності модифікованого крохмалю, як носія для іммобілізації ензимів та клітин мікроорганізмів.

\section{STUDY OF SAFETY INDICATORS MODIFIED STARCH ON WHITE MICE}

\author{
A. Vovkohon \\ Bila Tserkva National Agrarian University \\ Soborna Square, 8/1, Bila Tserkva, 09117, Ukraine
}

S U M M A R Y

Starch is widely used in the food industry. However, physicochemical properties make it possible to use this carbohydrate in other sectors of the national economy. The sorption properties of starch allow of adding organic compounds to it, including enzymes and microorganism cells. The starch may act as a carrier for immobilization of microorganisms. The advantages of starch as a carrier are its availability, renewal ability and relatively low cost. In order to increase the carrier capacity of starch, a work package on its modification by physicochemical methods was carried out in the laboratory of Research Institute of food technologies and technologies of processing of livestock products at the Bila Tserkva National Agrarian University.

The use of modified starch as a carrier for the cells' immobilization of ferment microorganisms for sour-milk products requires the study of its harmlessness. The study was conducted on linear mice with a body weight of 19-21 g. The modified starch was used in 
experimental animals by intra-gastric method using a metal probe. At the end of the experiment, the animals were slaughtered, their tissues and organs were taken for biochemical studies.

Experimentally, it was found that intra-gastric administration of $0.3 \mathrm{~cm}^{3}$ of $5.0 \%$ and $10.0 \%$ modified starch solution did not provoke any diseases or deaths of animals during experiment. The animal ethology was similar to that one of control mice. Introduction of increased doses of modified starch did not affect the external appearance of liver, spleen, kidney and digestive organs of animals.

The studies of protein metabolism data have shown that the activity of aspartate aminotransferase and alanine aminotransferase in the liver of mice fed by modified starch probably did not differ from similar data of animals fed by physiological solution. The difference in the total protein content in liver and urea in blood of experimental and control animals was not significant. Hemoglobin in blood of the mice after intra-gastric administration of different doses of the investigated factor was within limits of physiological norm.

Keywords: MODIFIED STARCH, INTRA-GASTRIC ADMINISTRATION, PROTEIN, AMINOTRANSFERASE, PROTEIN METABOLISM, LABORATORY ANIMALS.

\section{ИЗУЧЕНИЕ ПОКАЗАТЕЛЕЙ БЕЗВРЕДНОСТИ МОДИФИЦИРОВАННОГО КРАХМАЛА НА БЕЛЫХ МЫШАХ}

\section{А. Г. Вовкогон}

Белоцерковский национальный аграрный университет Соборная Площадь, 8/1, г. Белая Церковь, 09117, Украина

\section{А Н Н О Т А ЦИ}

Крахмал имеет широкое использование в пищевой промышленности. Однако физикохимические свойства позволяют использовать этот углевод в других отраслях народного хозяйства. Сорбционные свойства крахмала позволяют присоединять к нему органические соединения в том числе энзимы и клетки микроорганизмов. Крахмал может выступать носителем для иммобилизации микроорганизмов. Преимущества крахмала в качестве носителя заключаются в его доступности, восстанавливаемости и относительно невысокой стоимости. Для увеличения вместимости крахмала в качестве носителя в лаборатории НИИ пищевых технологии и технологий переработки продукции животноводства Белоцерковского национального аграрного университета проведен комплекс работ по его модификации физикохимическими методами.

Использование модифицированного крахмала в качестве носителя для иммобилизации клеток микроорганизмов заквасок для кисломолочных продуктов предусматривает изучение его безвредности. Данные исследования были проведены на линейных мышах с массой тела 19-21 г. Модифицированный крахмал опытным животным вводили внутрижелудочно с помощью металлического зонда. По завершению опыта животных забивали, отбирали ткани и органы для проведения биохимических исследований.

Экспериментально установлено, что при внутрижелудочном введении мышам по 0,3 $\mathrm{m}^{3}$ $5,0 \%$ и 10,0 \% раствора модифицированного крахмала заболеваний и гибели животных в течение всего эксперимента не отмечалось. Этология животных была аналогичной контрольным мышам. Введение повышенных доз модифицированного крахмала не повлияло на внешний вид печени, селезенки, почек и органов пищеварения животных.

Исследованиями показателей белкового обмена было доказано, что активность аспартатаминотрансферразы и аланинаминотрансферразы в печени мышей, которым водили модифицированный крахмал достоверно не отличалась от аналогичных данных у животных, которым водили физиологический раствор. Разница по содержанию общего белка в печени и 
мочевины в крови опытных и контрольных животных не имела достоверного характера. Гемоглобин в крови мышей после внутрижелудочного ведения им различных доз исследуемого фактора был в пределах физиологической нормы.

Ключевые слова: МОДИФИЦИРОВАННЫЙ КРАХМАЛ, ВНУТРИЖЕЛУДОЧНОЕ ВВЕДЕНИЕ, БЕЛОК, АМИНОТРАНСФЕРАЗЫ, ПОКАЗАТЕЛИ БЕЛКОВОГО ОБМЕНА, ЛАБОРАТОРНЫЕ ЖИВОТНЫЕ.

\section{Л I T E P A T У P A}

1. Starch-based films and food coatings: an overview. Starch/Staerke. / F. Versino, O. V. Lopez, M. A. Garcia, and N. E. Zaritzky. // 2016. Vol. 68, no. 11-12. pp. 1026-1037.

2. Improvement of water solubility and humidity stability of tapioca starch film by incorporating various gums. / S. R. B. Kim, Y. B. Choi, J.-Y. Kim, and S.-T. Lim. // LWT - Food Science and Technology. 2015. Vol. 64, no. 1, pp. 475-482.

3. Dry a matter content, starch content and starch yield variability and stability of potato varieties in Amhara Region of Ethiopia. / A. Tesfaye, S. Wongchaochant, T. Taychasinpitak and O. Leelapon. // Kasetsart J. (Natural Sci.) 2012. 46(5): P. 671-683.

4. Microalgae as New Sources of Starch: Isolation and Characterization of Microalgal Starch Granules. / Imma Gifunia, Giuseppe Olivieri, Irene Russo Kraussb, Gerardino D’Erricob, Antonino Pollioc, Antonio Marzocchellaa. // Chemical engineering transactions. 2017. Vol. 57. 1423-1428. DOI: $10.3303 /$ CET1757238

5. Microalgae-novel highly efficient starch producers. / I. Brányiková, B. Maršálková, J. Doucha, T. Brányik // Biotechnology and Bioengineering, 2011. 108 (4), 766-776.

6. Comparison of Cassava Starch with Corn as a Feedstock for Bioethanol Production. I Sarocha Pradyawong, Ankita Juneja, Muhammad Bilal Sadiq, Athapol Noomhorm and Vijay Singh // Energies, 2018. 11, 3476-3484. doi:10.3390/en11123476

7. Khamkeaw A. Hydrolysis of cassava starch by co-immobilized multi-microorganisms of Loog-Pang (Thai rice cake starter) for ethanol fermentation. // A. Khamkeaw; M. Phisalaphong // Food Sci. Biotechnol. 2016, 25, 502-516.

8. Soberanis C. R. Виділення та характеристика крохмалю, отриманого 3 Brosimum alicastrum Swarts Seeds. / C. R. Soberanis, D. Betancur-Ancona // Вуглеводні полімери. 2014, 101, 920-927.

9. An Efficient and Regenerable Quaternary Starch for Removal of Nitrate from Aqueous Solutions. / K. Chauhan, J. Kaur, P. Singh, P. Sharma, P. Sharma, G. S. Chauhan // Industrial and Ingegnering Chemistry Research, 2015. 55 (9), 2507-2519.

10. Біотехнологія / В. Г. Герасименко, М. О. Герасименко, М. І. Цвіліховський та ін.; За ред. В. Г. Герасименка. - К.:ІНКОС, 2006. - 647 с.

11. Water sorption and mechanical properties of cassava starch films and their relation to plasticizing effect / S. Mali, L. S. Sakanaka, F. Yamashita, and M. V. E. // Grossmann Carbohydrate Polymers, vol. 60, no. 3, pp. 283-289, 2005.

12. Water Sorption and Mechanical Properties of Starch/Chitosan Nanoparticle Films. / Siti H. Othman, Nurul R. A. Kechik, Ruzanna A. Shapi'i, Rosnita A.Talib, and Intan S. M. A. Tawakkal. // Journal of Nanomaterials. 2019. doi.org/10.1155/2019/3843949.

13. Landfeld A. Sorption and thermal properties of rice, potato starch, and oat flakes. / A. Landfeld, M. Houška, K. Hoke // Czech J. Food Sci., 2008. 26: 413-420.

14. Perez $S$. The molecular structures of starch components and their contribution to the architecture of starch granules: a comprehensive review / S. Perez, E. Bertoft // Starch Journal, 2010. $62,389-420$.

15. Isolation and characterization of starch obtained from Brosimum alicastrum Swarts Seeds.

/ E. Pérez-Pacheco, V. M. Moo-Huchin, R. J. Estrada-León, A. Ortiz-Fernández, L. H. May- 
Hernández, C. R. RíosSoberanis, D. Betancur-Ancona // Carbohydrate Polymers, 2014. 101, 920927.

16. Доклінічні дослідження ветеринарних лікарських засобів / [І. Я. Коцюмбас, О. Г. Малик, І. П. Патерега та ін. ]; під ред. І.Я. Коцюмбаса. - Львів: Тріада плюс, 2006. - 360 с.

17. Reitman S. A colorimetric method for the determination of serum glutamic oxalacetic and glutamic pyruvic transaminases / S. Reitman, S. Frankel.// Amer. J. Clin. Pthol. - 1957. - Vol. 28. P. 56.

18. Lowry O. H. Protein meashurement with the Folin phenol refgent / O.H. Lowry, N. I. Rosenbrough, A.L. Farr // J. Biol. Chem. - 1951. - Vol. 193. - P. 265-315.

19. Інструкція до набору реактивів для визначення концентрації гемоглобіну у крові (кат. № НР008.01.) Затверджена Інститутом АМН України від 10 жовтня 2003 року. - К., 2003. $-2 \mathrm{c}$.

20. Інструкція до набору реактивів для визначення сечовини в біологічних рідинах діацетилмонооксимним методом (кат. № НР018.01.) Затверджена Інститутом АМН України від 10 жовтня 2003 року. - К., 2003. - 2 с.

\section{References}

1. F. Versino, O. V. Lopez, M. A. Garcia, and N. E. Zaritzky. 2016. Starch-based films and food coatings: an overview. Starch/Staerke. Vol. 68, no. 11-12. pp. 1026-1037.

2. S. R. B. Kim, Y.-B. Choi, J.-Y. Kim, and S.-T. Lim. 2015. Improvement of water solubility and humidity stability of tapioca starch film by incorporating various gums. LWT - Food Science and Technology. Vol. 64, no. 1, pp. 475-482.

3. Tesfaye, A., S. Wongchaochant, T. Taychasinpitak and O. Leelapon. 2012. Dry a matter content, starch content and starch yield variability and stability of potato varieties in Amhara Region of Ethiopia. Kasetsart J. (Natural Sci.) 46(5): 671-683

4. Imma Gifunia, Giuseppe Olivieri, Irene Russo Kraussb, Gerardino D’Erricob, Antonino Pollioc, Antonio Marzocchellaa. 2017. Microalgae as New Sources of Starch: Isolation and Characterization of Microalgal Starch Granules. Chemical engineering transactions. VOL. 57. 14231428. DOI: 10.3303/CET1757238

5. Brányiková I., Maršálková B., Doucha J., Brányik T., 2011, Microalgae-novel highly efficient starch producers. Biotechnology and Bioengineering, 108 (4), 766-776.

6. Sarocha Pradyawong, Ankita Juneja, Muhammad Bilal Sadiq, Athapol Noomhorm and Vijay Singh 2. 2018. Comparison of Cassava Starch with Corn as a Feedstock for Bioethanol Production. Energies, 11, 3476-3484. doi:10.3390/en11123476

7. Khamkeaw, A.; Phisalaphong, M. Hydrolysis of cassava starch by co-immobilized multimicroorganisms of Loog-Pang (Thai rice cake starter) for ethanol fermentation. Food Sci. Biotechnol. 2016, 25, 502-516.

8. Soberanis C.R., Betancur-Ancona D., 2014, Виділення та характеристика крохмалю, отриманого з Brosimum alicastrum Swarts Seeds. Вуглеводні полімери. 101, 920-927.

9. Chauhan K., Kaur J., Singh P., Sharma P., Sharma P., Chauhan G.S., 2015, An Efficient and Regenerable Quaternary Starch for Removal of Nitrate from Aqueous Solutions. Industrial and Ingegnering Chemistry Research, 55 (9), 2507-2519.

10. Biotehnologia /V. G. Gerasimenko, M. O. Gerasimenko, M. I. Cvilihovskiy ta in.; Za red. V. G. Gerasimenka. - K.:INKOS, 2006. - 647 s.

11. S. Mali, L. S. Sakanaka, F. Yamashita, and M. V. E. Grossmann, "Water sorption and mechanical properties of cassava starch films and their relation to plasticizing effect," Carbohydrate Polymers, vol. 60, no. 3, pp. 283-289, 2005. 
12. Siti H. Othman, Nurul R. A. Kechik, Ruzanna A. Shapi’i, Rosnita A.Talib, and Intan S. M. A. Tawakkal. 2019. Water Sorption and Mechanical Properties of Starch/Chitosan Nanoparticle Films. Journal of Nanomaterials. doi.org/10.1155/2019/3843949.

13. Landfeld A., Houška M., Hoke K. (2008): Sorption and thermal properties of rice, potato starch, and oat flakes. Czech J. Food Sci., 26: 413-420.

14. Perez S., Bertoft E., 2010, The molecular structures of starch components and their contribution to the architecture of starch granules: a comprehensive review, Starch Journal, 62, 389420.

15. Pérez-Pacheco E., Moo-Huchin V.M., Estrada-León R.J., Ortiz-Fernández A., MayHernández L.H., RíosSoberanis C.R., Betancur-Ancona D., 2014, Isolation and characterization of starch obtained from Brosimum alicastrum Swarts Seeds. Carbohydrate Polymers. 101, 920-927.

16. Doklinichni doslidzennya veterinarnyh likarskyh zasobiv / [Kotsyumbas I. Y., Malyk O. G., Paterega I. P. ta in. ]; pid red. I. Y. Kotsyumbasa. - Lviv. Triada plus, 2006. - 360 s.

17. Reitman S., A colorimetric method for the determination of serum glutamic oxalacetic and glutamic pyruvic transaminases / Reitman S., Frankel S..// Amer. J. Clin. Pthol. - 1957. - Vol. 28. P. 56.

18. Lowry O.H. Protein meashurement with the Folin phenol refgent / O.H. Lowry, N. I. Rosenbrough, A.L. Farr // J. Biol. Chem. - 1951. - Vol. 193. - P. 265-315.

19. Instrukcia do naboru reaktyviv dlya viznachennya koncentracia gemoglobinu u krovi (kat. N HP008.01.) Zatverdzena Institutom AMH Ukrainy vid 10 zovtnya 2003 roku. - K., 2003. - 2 s.

20. Instrukcia do naboru reaktyviv dlya viznachennya sechoviny $\mathrm{v}$ biologichnych ridynach diacetilmonooksymnym metodom (kat. N HP018.01.) Zatverdzena Institutom AMH Ukrainy vid 10 zovtnya 2003 roku. - K., 2003. -2 s.

Рецензент - О. М. Мельниченко, д. с.-г. н., професор, Білоцерківський НАУ. 